\title{
Modification of English Complex Noun Phrases: A Case Study of Native and Non-Native Writers
}

\author{
${ }^{1}$ Rika Mutiara \\ ${ }^{1}$ Esa Unggul University, Jakarta \\ rika.mutiara@esaunggul.ac.id
}

Article History: Submitted March 27 ${ }^{\text {th }}, 2019$; Accepted May 21 ${ }^{\text {st }}, 2019$; Published July $5^{\text {th }}, 2019$

\begin{abstract}
This study aims at examining differences of complex noun phrases written by Indonesian writers and English native writers in English academic prose particularly undergraduate students' theses. The complex noun phrases were scrutinized based on how they were modified (Biber, Johansson, Leech, Conrad, \&Finegan, 1999, pp.588-644). Corpus method that is concordance analysis of nouns was applied to identify the modifications. The data were taken from four undergraduate theses. Two of them were written by non-native writers and the others were produced by native writers. The differences cover some modifiers namely adverb (phrase) as premodifiers and postmodifiers, adjective (phrase) as postmodifiers, relativizers, prepositional phrases, appositives, and multiple modifiers whether premodifiers or postmodifiers. The differences occur might be caused by L1 interference such as in the use of adjective (phrase), adverb phrase, and reflexive pronoun as postmodifier. Non-native writers do not produce any adjective (phrase) and reflexive pronoun as postmodifiers. For multiple premodifiers and postmodifiers, differences occur in the form of the highest number of modifiers in the NPs and their types. In the long noun phrases, the non-native writers modified the nouns with a number of appositives. NPs written bynative writers of English are more complex.
\end{abstract}

Keywords: noun phrases; academic; native and non-native writers; modification

\begin{abstract}
Abstrak.Penelitian ini menganalisa perbedaan frase nomina kompleks yang ditulis oleh penulis berbahasa jati bahasa Indonesia dan bahasa Inggris dalam tulisan akademik khususnya skripsi. Frase nomina tersebut dianalisa berdasarkan bagaimana penulis memodifikasi (Biber, Johansson, Leech, Conrad, \&Finegan, 1999, hal.588-644). Metode korpusya itu analisis konkordansi dari nomina diterapkan untuk mengidentifikasi modifikasi tersebut. Data dalam penelitian ini diambil dari empat skripsi. Dua di antaranya ditulis oleh penulis nonjati bahasa Inggris dan sisanya oleh penulis jati. Perbedaan meliputi modifikasi berikut: (frase) adverbial sebagai pramodifier dan posmodifier, (frase) adjektiva sebagai posmodifier, relativizer, frase preposisi, apositif, dan multi pramodifier dan posmodifier. Perbedaan ini mungkin disebabkan oleh pengaruh bahasa pertama misalnya dalam penggunaan (frase) adjektiva, frase adverb, dan pronomina reflexive sebagai posmodifier. Penulis nonjati bahasa Inggris tidak menghasilkan (frase) adjektiva dan pronomina reflexive sebagai posmodifier. Untuk multipramodifier dan posmodifier, perbedaannya adalah jumlah modifier dan jenisnya. Dalam frase nomina yang panjang, penulis nonjati bahasa Inggris memodifikasi nomina dengan sejumlaha positif. Frase nomina yang ditulis oleh penutur jati bahasa Inggris lebih kompleks.
\end{abstract}

Kata kunci: frase nomina; akademik; penulis jati dan nonjati; modifikasi 


\section{INTRODUCTION}

Payne (1999:258) states "the term noun is used to describe the class of lexical items whose prototypical members refer to entities (chair, film, leg), substances (butter, concrete, blood), and named individuals or locations (John, Paris, France)". A noun could occur with a determiner(s) or a modifier(s) to form a noun phrase. Biber et al. (1999.578-579) described clearly English noun phrases in several registers i.e. spoken, fiction, academic, and news. It was found that noun phrases (NPs) in academic and news registers occur more often than in other registers.

Besides the prominent frequencies, the variations of NP structures attack researchers' attention (Bennett, 2011; Biber et al., 1999; Cario-Pastor \& Luisa, 2009; Oakey, 2010). These variations occur because of the modifications of noun phrases. Most scholars categorized types of modification into premodifiers and postmodifiers. Premodifiers mean the modifiers come before the head nouns while postmodifiers show that the modifiers come after the head nouns. Sometimes both types of modifiers occur together. It is also possible for a head noun to have more than one premodifier or postmodifier. Therefore, the head noun has multiple premodifiers or postmodifiers. This study focuses on the noun phrases in academic register. In the academic register in which large information is conveyed, the use of such kinds of noun phrases occurs often (Biber et al., 1999:579; Oakey, 2010:194).

Some scholars studied the noun phrases in academic register. To find noticeable characteristics of NPs in academic register, Duskova (2009:29) compared how the nouns were modified in academic prose and fiction. The prominent modifiers in academic prose are coordination, appositive, and multiple postmodifiers such as in two relative clauses with another postmodification and two prepositional phrases followed by a postmodification. The result of the study shows that complex noun phrases are the noticeable features of academic writing compared to fiction (Duskova, 2009:32). Some modifiers are more common in academic prose such as adjective. Some multiple modifiers including multiple premodifiers, multiple adjectival coordination, and multiple apposition are also essential. The other essential modifier is -ing participial (Duskova, 34-44.).

Based on the description of characteristics of academic prose, the existences of phrasal (non-clausal) modifiers embedded in NPs show that academic prose is more compressed than elaborated (Biber and Gray, 2010:2). This finding gives insights into practitioners of academic writing the importance of teaching phrases. The general characteristic that it is compressed influences the kinds of salient modifiers such as nouns as premodifiers especially the use of three and four noun sequences. The other modifiers are prepositional phrase with ing-clause and appositive. The use of comma and parentheses to show appositive has been increasing.

Biber and Gray (2011:228-242) also investigated the modifiers. Nouns as premodifiers and prepositional phrases as postmodifiers are more varied. The variations include kinds of functions and words that frequently function as the heads. Noun phrases in academic prose have more dependent phrases such as adjectives, noun, and prepositional phrases. The complexity of the structures can be seen in the phrases without verbs. Some noun phrases have more nouns or adjectives as premodifiers. In the case of postmodification, prepositional phrases which commonly appear as in and for and then were followed by ingclauseraise. Appositive tends to be more complex to give more specific and technical 
information. From this study, the importance of phrases to convey more information is seen obviously.

As there has been a phenomenon in applied linguistics to compare writings of native and non-native writers because they have different linguistic backgrounds, some scholars scrutinized how various native and non-native scholars modified noun phrases (CarrioPastor and Luisa, 2009:226). The factor of different linguistic backgrounds can contribute to the different use of structures. Noun phrases produced by non-native writers are more complex than the ones written by native writers. This finding is surprising because it was predicted that more complex noun phrases would be written by native writers.

Another study that contrasted different kinds of NPs written by two groups of language users was conducted by Bennett (2011:182-198). The NPs were written by scholars and students of university. The result of the study shows that the two groups of writers use modification differently for definite article, premodification, and premodification and postmodification that occur at the same time in an NP. In using premodifiers, the scholars used various kinds while the students mostly produced adjective. In the prepositional phrases, the scholars dominantly used of. On the contrary, the students used various kinds of prepositions. For relative clauses, the scholars focused on relativizerwhich. In contrast, the students used that. The results of the study were used as input to develop learning materials.

The previous studies mostly discussed the noun phrases in different registers (Biber, et al., 1999:589; Duskova, 2009:29). It covers the simple and complex noun phrases. Another study that focuses on academic prose did not contrast the writings of students with different linguistic background, English native writers and non-native writers (Bennet, 2011). Carrio-Pastor and Lusia (2009:226) contrasted scholars' writings produced by native and non-native writers. Moreover, it sought the differences of modifiers produced by the two groups. The results of the study raised a question because it was found that the more complex NPs were produced by non-native writers (Carrio-Pastor and Lusia, 2009:229). In addition, to the best of my knowledge, the previous studies discuss all noun phrases (simple and complex noun phrases), there is no study that focuses on complex noun phrases. This study aimed at contrasting complex NPs used by native and non-native writers. This study sought to answer the following research questions:

1. What are the kinds of modification in complex NPs that occur in the undergraduate theses written by the native and non-native writers?

2. What are the differences of modification in complex NPs written by native and non-native writers?

\section{Classification of Modifiers}

The classification of modifiers developed by Biber et al. (1999:588-605) was used in this study. For the category of appositive, one sub-category (appositive with indicators) that was based on the work of Greenbaum (1996:231) was adopted. Overall, modifications are categorized into premodification and postmodification. For premodification, they are divided into:

1. general adjective such as political isolation

2. ed-participial modifier such as fixed volume

3. ing-participial modifier such as exhausting task 
4. noun such asmarket forces

5. multiple premodifier such as high sulphur soil areas

6. coordinatedpremodifier such as hot and hardening mud.

Postmodification consists of clausal postmodification and non-clausal postmodification. Clausal postmodification are separated into five kinds namely

1. relative clause such as a footpath which disappeared in a landscape of fields and trees

2. to-clause such as one of the key contenders to mount a rescue bid for Ferranti

3. ing-clause such as a rebels advancing rapidly southwards

4. ed-clause such as fury fanned by insensitive press coverage

5. noun complement clause such as an industry trade group's report that its leading indicator fell in September

The noun complement clause was not included in this study because it covers semantic meaning and this study only focuses on the structure of the modification.

Non-clausal postmodification consists of 6 modifications as follows:

1. prepositional phrase such as the sale, for a sum not thought to be material

2. adverb (phrase) such as way out

3. adjective (phrase) such as any way possible

4. reflexive pronouns such as the arlines themselves

5. appositive noun phrase

- appear in parentheses such as another technique (the 'Wheeler linkage')

- appear directly (restrictive) such as reflectivity $R$

- appear after punctuation e.g. comma such as Mr. PyotrLuchinsky, the new secretary

- appear with indicators e.g. such as and for instance such as the great musicians such as John Lenon and Mariah Carey

6. multiplepostmodifier such as a written document known as "the constitution" which lays down the main rules.

\section{METHOD}

The data were taken from four theses. Two of them were written by English native writers and the two others were produced by non-native writers whose L1 is Indonesian. The topics of the theses are English language learning, English dialect of particular place, the use of English grammar, and students' errors in using English. The data collection was done by downloading the theses from the university websites. They were published within 2010-2013. Before coding the noun phrases, the theses were read to make sure they were written clearly. The theses were saved into txt file in order to be run into Antconc program. The noun phrases occur in the sections of introduction, literature review, methodology, findings and discussion, and conclusion. Noun phrases in the tables, charts, direct quotation, and titles were not included in the corpora. There are four corpora and each of them represents one thesis. The size of each corpus can be seen in the table 1 . 
Table 1 The size of each corpus

\begin{tabular}{lllll}
\hline Corpus & Non-native A & Non-native B & Native A & Native B \\
\hline Size & 542 & 606 & 552 & 385 \\
\hline Total size & \multicolumn{2}{c}{1148} & & 937 \\
\hline
\end{tabular}

The study applied corpus approach namely word list and concordance study to examine the modifications of the complex noun phrases. To study the concordance lines, it is necessary to decide what nouns to be seen in concordance lines. To obtain the nouns, observing words in a word list was conducted. A word list from each of the corpora was made by running the files of the theses in AntConc program. All words that occur in the corpus appeared in the word list. The words in the word lists that belong to nouns were selected manually by the researcher.

After the nouns were obtained, the next step is studying the concordance lines. In doing it, non-noun occurrences and nouns which do not function as the head of the phrases were discarded. Examining non-noun occurrences is essential because some words have two classes of words, for example, book can be a verb and a noun. Through scrutinizing the concordance lines, the occurrence of the word as a verb or a noun was decided by the researcher. The following is the example how the steps were conducted. This example only focuses on the noun vocabulary.

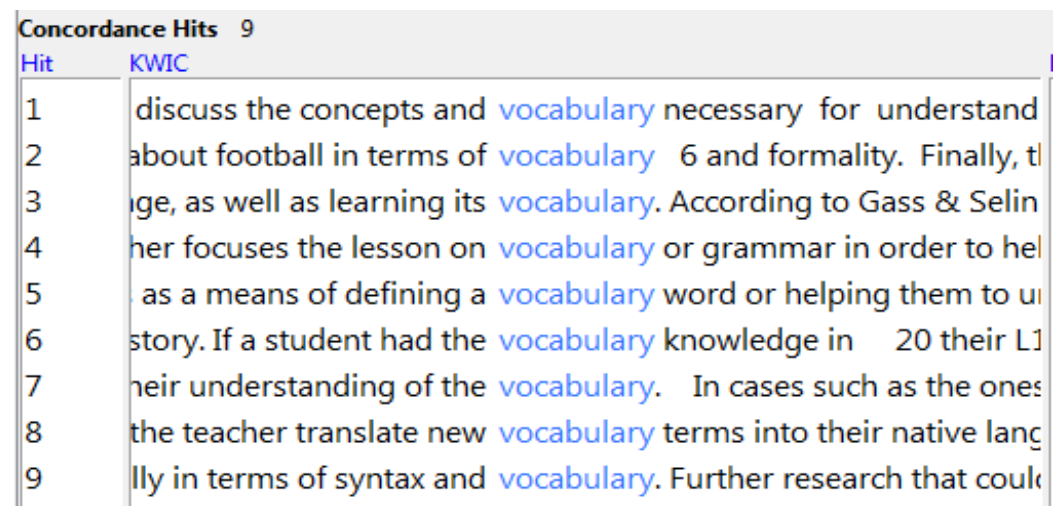

Figure 1 The occurrences of vocabulary in concordance lines

One of the nouns is vocabulary. The noun phrases that were analyzed are the ones with modifiers. Therefore, a noun phrase such as a vocabulary was excluded from the analysis because no modifier exists. When a noun exists with a modifier and a determiner such as $a$, the, some, etc, the determiner was not counted in doing the analysis. The occurrence of the determiner does not influence the modification of the noun phrases.

Based on concordance investigation, a vocabulary word and the vocabulary knowledge were found. The word vocabulary does not function as the heads in both NPs. It functions as a modifier that comes before the head. In avocabulary word, it modifies word. In the vocabulary knowledge, it modifies knowledge. In the phrase vocabulary necessary for understanding vocabulary is the head and necessary for understanding is the postmodifier (adjective phrase). Such kind of noun phrase was analyzed in detail.

It is possible for noun phrases to have premodifiers and postmodifiers at the same time such as the thick book that I borrowed from you. This noun phrase was categorized as a noun phrase with a complex head and a postmodifier. The complex head occurs when a 
head is modified by premodifier(s) besides postmodifier(s). In that case, the complex head is the thick book and the postmodifier is that I borrowed from you.

\section{RESULTS AND DISCUSSION}

Native writers produced all kinds of modifiers. In contrast, some kinds of modifiers do not occur in non-native writers' theses such as adjective (phrase), adverb (phrase), and reflexive pronoun. The differences of the modifiers made by the two groups of writers were discussed in the following section.

\section{Premodification}

The differences of how non-native writers and native writers used premodifiers includes gradable adjectives, the use of compound noun in multiple premodifiers, coordinated premodifiers, -ed participial, and uncategorized premodifiers as shown in the table 2.

Table 2 The differences of premodification

\begin{tabular}{|c|c|c|}
\hline Differences & Non-native writers & Native writers \\
\hline Gradable adjective & $\begin{array}{l}\text { more } \\
\text { e.g. more comprehensive data }\end{array}$ & $\begin{array}{l}\text { more, less, much, and much+ } \\
\text { er } \\
\text { e.g. much lower income }\end{array}$ \\
\hline $\begin{array}{l}\text { The use of compound noun in } \\
\text { multiple premodifiers }\end{array}$ & Do not exist & $\begin{array}{l}\text { Exist (e.g. middle class) } \\
\text { e.g. the core middle class } \\
\text { white population }\end{array}$ \\
\hline Coordinated premodifiers & $\begin{array}{l}\text { Produce more various } \\
\text { coordination such as or, either } \\
\text { or, and both and } \\
\text { e.g. either the interference or } \\
\text { intralingual factors }\end{array}$ & $\begin{array}{l}\text { Produce only and } \\
\text { e.g. an older and more } \\
\text { recognizable term }\end{array}$ \\
\hline -edparticipial & $\begin{array}{l}\text { Irregular verb } \\
\text { e.g. the shown examples }\end{array}$ & $\begin{array}{l}\text { Regular verb } \\
\text { e.g. mixed feeling }\end{array}$ \\
\hline Uncategorized premodifiers & $\begin{array}{l}\text { Use parentheses } \\
\text { e.g. first language (henceforth, } \\
\text { L1) interference }\end{array}$ & Do not exist \\
\hline
\end{tabular}

Non-native writer modified the noun by using parentheses. The information given in the parentheses is in the form of words.

\section{General Adjective}

The two groups of writers produced adjectives as modifiers. This type of modifier occurs with and without determiner. Some lexical variations exist to form gradable adjectives, for instance, the native writers used more variation i.e. more, less, and much. Much also occurs with gradable form such as in much lower.

\section{ed-participial modifier}

Irregular verb occurs in non-native writer's thesis and the regular verb appears in the native writer's thesis. Non-native writers put some words in the parentheses as a part of modifier such as in first language (henceforth, L1) interference. This kind of modifier never occurs in the native writers' theses. 


\section{ing-participial modifier}

Both native and non-native writers produced this type of modifier. It might appear with genitive of singular noun as in the writer's teaching practicum.

\section{Noun}

Compound nouns appear as modifiers in both groups' theses such as ten high school studentsin non-native writers' theses and mobile phone companies in native writers' theses.

\section{Multiple Premodifier}

A compound noun i.e. middle class was used as a modifier in the noun phrase (the core middle class white population). This case does not occur in non-native writers' theses. There is an existence of modifiers in the form of gradable adjectives in the native writer's thesis as in an older and more recognizable term. The first modifier was formed by adding morpheme $-e r$ to the adjective old. The second gradable modifier exists with the word more. In this case, more complex process occurs to build the noun phrase.

\section{Coordinated Premodifier}

Another case of lexical variation occurs in the coordinated premodifiers. The non-native writers produced more lexical variations to show coordination.

\section{Postmodification}

All types of postmodification were produced by all writers. In relative clauses and prepositional phrases, it was found that the variations are related to lexical items. In relative clauses, they produced different relativizers. In prepositional clauses, they used different prepositions

\section{Relative clause}

Both groups used various kinds of relativizers and zero relativizer. The table 3 shows detailed information about the differences of relativizers.

Table 3 The differences of relative clauses

\begin{tabular}{lll}
\hline Differences & Non-native writers & Native writiers \\
\hline Relativizers & Use some relativizer, but it Vary especially in \\
& only has one kind of combination of prep+which \\
& prep+which i.e. in which & such as in which, on which, at \\
& e.g. "The good things doesn't which, and by which \\
& mean right in which the e.g. the rate at which each \\
& subject is plural countable informant drops post-vocalic \\
& noun & $(r)$
\end{tabular}

The finding that native writer produced more relativizers in the form of preposition+which is similar to the finding of Biber et al. (1999, p. 625). Some relativizers such as whereby, whom, and when also do not occur in non-native writers' theses. It is only relativizerwhythat occurs in non-native writers' theses but it was not produced in native writers' theses. It can be said that native writers produced more various relativizers. In the case of relative clause with zero relativizer, there is no difference between two groups. 
Both groups produced this type of modifier. To form complex heads, non-native writers used adjective, compound noun and-ingparticipial as in the error analysis method suggested by Corder. The head is method and it was preceded by a compound noun (error analysis).The complex heads in native writers' theses are different. The heads were modified by noun, adjective, and uncategorized premodifiers as in the linguistic features that accompanied them. In this complex noun phrase, the complex head is the linguistic features. The head was modified by linguistic as a premodifier and then the complex head was modified with a postmodifier (that accompanied them). The uncategorized premodifier appears as a phrase as in the "poverty of the stimulus" argument which advocated that positive evidence. The head was formed into complex head by having "poverty of the stimulus" as the premodifier. The premodifier is a phrase. Then, this complex head (the "poverty of the stimulus" argument) was followed by a relative clause (which advocated that positive evidence).

\section{to-clause}

The differences of NPs produced by native and non-native writers are in the complex heads. The heads are called complex because they are not only modified by to clause but also by premodifiers. To build complex heads in to clause, there are adjective as in their inherent need to communicate and coordinated premodifiers as in a direct inspiration and motivation to conduct this study in native writers' theses. In their inherent need to communicate, the complex head is their inherent need.

\section{ing-clause}

Both types of writers produced this type of postmodifier. However, the non-native writer produced learning for the verbs such as in Chinese and Japanese learners learning English. It might occur because of the topic of the writing.

\section{ed-clause}

These types of modifiers were produced by all writers. One of the native writers used being before the verb such as in linguistic variable being studied. This existence of lexis being is related to the tense. The head was modified by inherent to form the complex head. In the non-native writer's thesis, the complex head was built by using adjective as in the commonest errorsccurred. The complex head is the commonest errors. The head is errors that is modified by commonest.

\section{Prepositional phrases}

Table 4 shows the differences of how non-native writers and native writers use prepositional phrases to build complex NPs.

Table 4 The differences of prepositional phrases

\begin{tabular}{llll}
\hline Differences & & Non-native writers & Native writers \\
\hline $\begin{array}{l}\text { Prepositions that are not } \\
\text { produced }\end{array}$ & $\begin{array}{l}\text { behind, through, over, and } \\
\text { during }\end{array}$ & around, by, before, and within \\
\hline offin+ing-clause & Only preposition of & Prepositions of and in \\
\hline
\end{tabular}

Non-native writers did not produce some prepositions such as behind, through, over, and during. Native writers did not make some prepositions i.e. around, by, before, and within. Some noun phrases are followed by -ing clause. It happens when prepositions in and of 
were used by non-native writers such as in the convenient sampling in selecting the researcher participants. In the case of native writers, ing-clauses occur after prepositions of that is the old habit of speaking the mother tongue language. This finding is in line with the findings from Biber and Gray (2011). This type of modifier is a feature of academic prose (pp. 241-242). Noun, adjective, and multiple premodifiers, and uncategorized premodifier occur as the modifiers that build the complex heads in non-native writers' theses. When the heads are called complex, the heads are modified by the premodifier. They are not only nouns. The example is a negative verb with be. Negative which modifies verb forms the complex head. The head is modified by a prepositional phrase (with be). Noun, adjective, multiple premodifiers, uncategorized premodifier, and coordinated premodifier exist to build the complex heads in the theses of native writers' theses such as in the test result from the 2007 students. The types of modifiers that build complex heads in native writers are more various.

\section{Adjective (phrase)}

In native writers' theses, the modifier exists as in things natural and independent and the neighborhoods surrounding theirs. In things natural and independent, the head is things. The head is modified by natural and independent. In the neighborhoods surrounding theirs, the head is neighborhoods that is modified by surrounding theirs. There are no occurrences of adjective and adjective phrase as modifiers in non-native writers' theses. Biber et al. (1999) stated that adjective (phrase) does not have high frequency in English (p. 604). This fact might lead the non-native writers not to get sufficient exposure to this type of modifiers. Another reason might be L1 interference. In English, adjectives could occur before or after the head (Biber et al., 1999). For instance, in small house, the head is house. The adjective (small) modifies house. The adjective occurs before the head (premodifier). In any way possible, the head is way and it is modified by an adjective (possible). The adjective occurs after the head (postmodifier). However, in Indonesian, the occurrence is always after the head (postmodifier). This kind of noun phrase for example bukubaru will have a premodifier when it is translated into English (new book). There is only one position of adjective as a modifier in Indonesian and they bring this concept when they write in English. There are no occurrences of complex heads made by both groups.

\section{Adverb (phrase)}

Adverb and adverb phrase occur in native writers' theses such as in figure 11 below and middle class, predominantly white non-Hispanic neighborhoods. It is only adverb that occurs in non-native writers' theses as in the studies above. The adverb phrase was not found in non-native writers' theses. It might be the influence of L1 that causes this phenomenon. Alwi, Soenjono, Lapoliwa, \&Moeliono (2000) mention that adverb and adverb phrase cannot modify noun in the phrase level of Indonesian (p. 197). Structural translation might play a role here. They use the concept to modify nouns in Indonesian when they construct noun phrases in English. According to Biber et al. (1999), adverb and adverb phrase are less frequent modifiers in LGSW (Longman Grammar of Spoken and Written) corpus (p. 604). This fact may affect the non-occurrence of adverb phrase in nonnative writers' theses. They might be exposed to less modifiers of this type. It requires more complex modification process to form adverb phrase. A noun is modified not only by a word (adverb) but also by a phrase (adverb phrase). 


\section{Reflexive pronoun}

Reflexive pronouns itself as in the word itself and themselves as in the students themselves were found in native writers' theses. However, this kind of modifier does not occur in nonnative writers' theses. Among all modifiers of noun phrases in Indonesian, the concept of reflexive pronoun as a modifier does not exist (Alwi, et al., 2000, pp. 244-248). It might be the cause of non-existence of such modifier in non-native writers' theses.

\section{Appositive}

Biber et al. (1999:638) stated appositive noun phrases "have equivalent status with the preceding (head)". It is possible for the nouns to be followed by punctuation and then the modifiers occur. Biber et al. gave a comma as the example of the punctuation. It is found that colon is another type of punctuation that can be used. In the noun phrase written by a non-native writer, the modifier occurs with quotation mark as in the question: "Which factors have a bigger impact on the English writing, the interference or intralingual factors?". Furthermore, appositive shown by comma does not exist in the non-native writers' theses. The differences of appositive are as follows.

Table 5 The differences of appositive

\begin{tabular}{|c|c|c|}
\hline Differences & Non-native writers & Native writers \\
\hline Appositive in parentheses & $\begin{array}{l}\text { Show examples, acronym, } \\
\text { percentage, additional } \\
\text { information, or words that } \\
\text { show attachment, table, or } \\
\text { figure. } \\
\text { e.g. 2,000 tweets (originating } \\
\text { from the US and in English) }\end{array}$ & $\begin{array}{l}\text { Present examples, acronym, } \\
\text { percentage } \\
\text { e.g. Students with Interrupted } \\
\text { Formal Education (SIFE) }\end{array}$ \\
\hline $\begin{array}{l}\text { Appositive } \\
\text { punctuation }\end{array}$ & $\begin{array}{l}\text { Colon } \\
\text { e.g. the question: "Which } \\
\text { factors have a bigger impact } \\
\text { on the English writing, the } \\
\text { interference or intralingual } \\
\text { factors?" }\end{array}$ & $\begin{array}{l}\text { Comma and colon } \\
\text { e.g. off-task, non-academic } \\
\text { activities } \\
\text { e.g. certain conditions: that } \\
\text { the speaker have enough time } \\
\text { to process their message, that } \\
\text { the speaker be focused on } \\
\text { conveying their message } \\
\text { correctly, and that the speaker } \\
\text { have a clear enough } \\
\text { understanding of the rule that } \\
\text { he or she is attempting to } \\
\text { apply }\end{array}$ \\
\hline Appositive with indicators & $\begin{array}{l}\text { for instance, especially, in } \\
\text { particular, and such as } \\
\text { e.g. the tenses in particular } \\
\text { simple past tense }\end{array}$ & $\begin{array}{l}\text { such as, namely, and including } \\
\text { e.g. a more formal situation, } \\
\text { such as with their bilingual } \\
\text { employer }\end{array}$ \\
\hline
\end{tabular}

Appositive with parentheses in non-native writers has more functions. It shows that the writers try to give information in detail. This finding is in line with what was mentioned by Biber et al. (1999, p. 579). As academic prose carries a lot of information, the writers put the information in the parentheses. In the indicators for the appositive, the non-native writers produced more types of indicators. There are four types of indicators such as for instance, especially, in particular, and such as. Two of them (for instance and such as) 
indicate examples while especially and in particular show their concerns. In the native writers' theses, such as was used. To add more information, namely and including were produced. In the uncategorized appositive, non-native writers made more various appositive.

Both groups also produced appositive that comes directly after the heads such as Labov 2006 in the thesis of native writer. In this noun phrase, there are no indicators nor quotation marks. Adjective and uncategorized premodifiers exist to build complex head in nonnative writers' theses as in a "RT" sign (stands for ReTweet). Adjective and compound noun occur as premodifiers for the heads in native writers' theses.

\section{Multiple postmodifier}

The differences of multiple postmodifiers produced by two groups of writers can be seen in table 6.

Table 6 The differences of postmodification

\begin{tabular}{|c|c|c|}
\hline Differences & Non-native writers & Native writers \\
\hline $\begin{array}{l}\text { Combinations of kinds } \\
\text { of postmodifiers }\end{array}$ & $\begin{array}{l}\text { Adjective (phrase), adverb } \\
\text { (phrase), and reflexive pronoun } \\
\text { never occur. }\end{array}$ & All kinds of modifiers exist \\
\hline $\begin{array}{l}\text { Dominant kinds of } \\
\text { postmodifiers in the } \\
\text { longest NPs }\end{array}$ & $\begin{array}{lll}\begin{array}{l}\text { Prepositional phrases } \\
\text { appositive }\end{array} & \text { and } \\
\end{array}$ & Prepositional phrases \\
\hline The longest NP & An NP with 8 postmodifiers & An NP with 9 postmodifiers \\
\hline $\begin{array}{l}\text { Types of postmodifiers } \\
\text { that occur repeatedly in } \\
\text { noun phrases with } 2 \\
\text { postmodifiers }\end{array}$ & $\begin{array}{l}\text { Prepositional phrases and relative } \\
\text { clauses. }\end{array}$ & $\begin{array}{l}\text { Prepositional phrase, } \\
\text { clauses, and appositives }\end{array}$ \\
\hline 3 postmodifiers & $\begin{array}{l}\text { Adjective (phrase), adverb } \\
\text { (phrase), and reflexive pronoun do } \\
\text { not occur. }\end{array}$ & All kinds of modifiers occur. \\
\hline 4 postmodifiers & $\begin{array}{l}\text { To clause, adjective (phrase), and } \\
\text { adverb (phrase) do not exist }\end{array}$ & $\begin{array}{l}\text { Adverb (phrase) and reflexive } \\
\text { pronoun do not exist }\end{array}$ \\
\hline $\begin{array}{l}\text { More than } \\
\text { postmodifiers }\end{array}$ & $\begin{array}{l}\text { To clause, ing-clause, adjective } \\
\text { (phrase), adverb (phrase), and } \\
\text { reflexive pronoun do not appear. }\end{array}$ & $\begin{array}{l}\text { Adjective (phrase), } \\
\text { (phrase) do not appear. }\end{array}$ \\
\hline
\end{tabular}

To modify the nouns, non-native writers never use the less frequent modifiers such as adjective, adverb, and reflexive pronoun as postmodifiers. These modifiers also do not exist in the noun phrases with single postmodifier. Native writers produced all types of modifiers. The more complex the postmodifiers, the more limited kinds of modifiers the writers produced.

The longest NP produced by non-native writer has eight postmodifiers and prepositional phrases and appositive are dominant here. It is some cases [of the misformations [of the linking verb [was/were], [in which the subject used the singular verb [was] [in place [of the plural linking verb [were][]]]]. The longest NP produced by a native writer has nine postmodifiers and prepositional phrases are the salient features. It is the learning patterns [of bilinguals [at all levels [of English language acquisition]], [from those [learning their first words [of English] [to those [that appear to have almost full mastery [of the language []]]]]. Prepositional phrases as modifiers occur frequently on it. Relative clause 
and -ing clause also occur once for each. It also has complex head the learning pattern. In the noun phrases with 2 postmodifiers, some modifiers may occur repeatedly in a noun phrase. Prepositional phrases and relative clauses appear repeatedly in the theses of nonnative writers. As a result, the patterns of relative clause+relative clause and prepositional phrase+prepositional phrase occur. These patterns also exist in the native writers' theses. Besides these two patterns, another pattern in the native writers' theses is appositive+appositive. In the NPs with three postmodifiers, three prepositional phrases exist in some noun phrases produced by non-native and native writers. In forming the complex heads, the non-native writers and native writers used noun, adjective, multiple premodifiers, coordinated premodifiers, and uncategorized premodifier such as acronym.

\section{CONCLUSION}

The non-existence of some types of modifiers only occurs in non-native writers' theses. Those modifiers are adjective (phrase), adverb phrase, and reflexive pronoun. They were mentioned by Biber et al. (1999) as less frequent modifiers (p. 604). They also do not exist in Indonesian. Therefore, these two facts may cause their non-existence in non-native writers' theses. Noun phrases with those modifiers always occur as non-complex heads. The heads were modified only by postmodifiers. Non-native writers also produced only preposition in that is followed by -ing clause. On the contrary, native writers made prepositions in and of before -ing clause. Non-native writers created more types of appositive. In the case of multiple postmodifiers, the dominant modifiers in non-native writers' theses are appositive and prepositional phrases while the native writers used prepositional phrases.

The present study shows that native writers produced more complex noun phrases than non-native writers. It is different from the result of the previous study (Carrio Pastor and Luisa, 2009, p 229). Because the present study only used undergraduate theses written by four writers, the results cannot be used to generalize the characteristics of English complex noun phrases written by Indonesian students. The implication of the present study is to give more emphasis on the less frequent modifiers. It can be done by including them in the syllabus of academic writing. By doing so, the students will get more exposure and give more attention to them. Further studies can be done by having larger data and covering more types of texts such as final term papers and daily assignments.

\section{REFERENCES}

Alwi, H., Soenjono, D., Lapoliwa, H., \&Moeliono, A. M. (2000).Tata bahasabakubahasa Indonesia. BalaiPustaka: Jakarta.

Anthony, L. (2014). AntConc (Version 3.4.3) [Computer Software]. Tokyo, Japan: Waseda University. Available from http://www.laurenceanthony.net/

Bennett, G. (2011). A staircase model for teaching grammar for EAP writing in the IEP: Freshmen composition and the noun phrase. (Dissertation, University of Birmingham, Birmingham). Retrieved from http://etheses.bham.ac.uk/2972.

Biber, et al. (1999).Longman grammar of spoken and written English. London: Longman. 
Biber, J. \& B. Gray. (2010). Challenging stereotypes about academic writing: Complexity, elaboration, explicitness. Journal of English for Academic Purposes 9, 2-20.doi: 10.1016/j.jeap.2010.01.001

Biber, D. \& B. Gray. (2011). Grammatical change in the noun phrase: The influence of written language use. English Language and Linguistics 15(02), 223-250.doi: $10.1017 / \mathrm{S} 1360674311000025$

Cario-Pastor, M \& Luisa. (2009). Contrasting specific English corpora: Language variation. International Journal of English Studies, 221-233.

Duskova, L. (2009). Noun modification in fiction and academic prose.Brno studies in English. 35(2), 29-51.

Greenbaum, S. (1996).The Oxford English grammar. Oxford: Oxford University Press.

Oakey, D. (2010). Understanding noun phrases.In S. Hunston\& D. Oakey.Introducing applied linguistics: Concepts and skills. (pp. 191-198). Routledge: New York. 